\title{
Aféra JUDr. Mitlöhnera: Analýza prípadu a obecnější souvislosti
} Lukáš Novák

\section{Základní fakta}

V prvním loňském čísle Časopisu zdravotnického práva a bioetiky publikoval JUDr. Miroslav Mitlöhner, CSc, tehdy ředitel Ustavu sociální práce Univerzity Hradec Králové, článek nazvaný „K právním a etickým problémům spojeným s narozením těžce malformovaného jedince“, v němž obhajuje zavedení praxe nucených interrupcí a infanticidy "těžce malformovaných jedinců“ , a to bez souhlasu rodičů, na základě rozhodnutí lékaře. Článek byl prezentován jako výstup projektu Rozvoj a podpora multidisciplinárního vědecko-výzkumného týmu pro studium současné rodiny na UHK (RODINA-UHK-CZ.1.07/2.3.00/20.0209). ${ }^{2}$

Na webu Zdravotnické právo a bioetika se v zápětí rozvinula krátká diskuse, ${ }^{3} \mathrm{v}$ níž bylo poukázáno na velmi nízkou vědeckou úroveň článku a morální odpudivost autorem hájených tezí. Šéfredaktor Tomáš Doležal rozhodnutí redakce článek publikovat obhajoval s tím, že si sice není jist jeho vědeckou úrovní, nicméně nakonec se redakční rada rozhodla jej publikovat, nebot' ,je to příspěvek, který by mohl vyvolat ostrou reakci a třeba i polemiku již na odbornější úrovni“, a "nejvhodnější obranou je diskuse a argumentační obrana, resp. racionální analýza prokazující, že teze zastávané autory je možné vyvrátit“. ${ }^{4}$

Následně se ukázalo, že Mitlöhnerův článek je autoplagiát, článek totiž již (s drobnými odchylkami) vyšel v časopise Československé zdravotnictví (1986). ${ }^{5}$ Poté co se redakční rada o této skutečnosti dozvěděla, vydala následující prohlášení:

„Vzhledem $k$ tomu, že byl redakci ČZPaB doručen podnět, který se týká pưvodnosti článku JUDr. Mitlöhnera - K právním a etickým problémům spojeným s narozením těžce malformovaného jedince, byla redakční rada nucena se tímto podnětem zabývat.

Jednou z podminek možnosti publikace článku je skutečnost, že př́spěvek nebyl dosud publikován ani není v současnosti zaslán do jiného časopisu pro posouzení (nebo bylo podáno vysvětlenív Komentárích pro editora). Toto pravidlo je obsaženo v Pokynech pro autory a je nezbytným predpokladem pro publikaci článku. Tato podmínka byla v př́padě článku JUDr. Mitlöhnera porušena, nebot' př́spěvek byl již publikován v Čs. Zdrav., 34, 1986, No. 3, p. 108-113 a autor redakci o této skutečnosti neinformoval.

Jednání autora shledala redakční rada za eticky zcela neprijatelné, poškozující dobré jméno časopisu a jeho vydavatele.

\footnotetext{
1 (c) Miroslav MITLÖHNER, K právním a etickým problémům spojeným s narozením těžce malformovaného jedince, Časopis zdravotnického práva a bioetiky 1/2014, dostupné na: http://www.ilaw.cas.cz/medlawjournal/index.php/medlawjournal/article/view/64, citováno dne 13. 6.2014 (dále jako „autoplagiát“).

2 Srov. tamtéž.

3 Srov. diskuse pod př́spěvkem: ( ) Tomáš DOLEŽAL, Oznámení o vydání nového čísla časopisu, Zdravotnické právo a bioetika (on-line), dostupné na: http:/ / zdravotnickepravo.info/oznameni-o-vydani-noveho-cisla-casopisu/, citováno dne 13. 6. 2014.

4 Tamtéž.

5 Srov. Miroslav MITLÖHNER, K právním a etickým problémům spojeným s narozením těžce malformovaného jedince, Československé zdravotnictví 3/1986, s. 108-113 (dále jako „původní článek“).
} 
Z tohoto di̊vodu se redakční rada rozhodla pro uplatnění zákazu publikace dalších článků JUDr. Mitlöhnera na stránkách ČZPaB, nebot' porušení základních pravidel a etických principů vědecké práce nelze tolerovat." 6

Kauza získala rychle mediální publicitu. Mitlöhner byl podroben z mnoha stran ostré kritice ${ }^{7}$ a rezignoval na místo ředitele Ústavu sociální práce a na místo člena vědecké rady Ministerstva práce a sociálních věcí; na jeho obranu však vystoupil např. dr. Radim Uzel ${ }^{8}$ a celou „mediální kampaň“ proti Mitlöhnerovi též odsoudili Tomáš Doležal a David Černý z redakce Časopisu zdravotnického práva a bioetiky jako "hon na čarodějnice“, který podle nich znemožňuje žádoucí diskusi o věcné podstatě problému - byt” obsahově s Mitlöhnerovými názory autoři „rezolutně nesouhlasí". ${ }^{9}$

Text, který následuje, je pokusem o komplexní analýzu různých aspektů celé kauzy, která by měla vyústit v zaujetí racionálního stanoviska. ${ }^{10}$

\section{Analýza př́ípadu}

\subsection{Autoplagiátorství}

Toto je jediná rovina kauzy, na kterou redakce časopisu původně reagovala (následná vyjádření redaktorů Černého a Doležala se nevztahují ani tak k samotnému Mitlöhnerovu článku, jako spíše k pozdvižení, které vyvolal), a to z pozice bezprostředně poškozené strany: to ona byla především podvedena, a proto přijala patřičné opatření - zákaz další publikace v daném časopise pro viníka. Na první pohled by se tedy zdálo, že na této rovině je věc vyřízena ovšem není tomu tak zcela. Role oběti, do níž se staví redakce časopisu, není totiž zcela na místě. Časopis zdravotnického práva a bioetiky chce být vědeckým časopisem, publikované články tudíž mají podléhat adekvátnímu recenznímu řízení, které by mělo být zárukou jejich odborných kvalit. Jak je možné, že si recenzenti nevšimli, že článek naprosto nereflektuje aktuální odbornou debatu k tématu, že jediné citované zdroje jsou obskurní texty třicet let staré a v po-

6 Prohlášení již není na webu časopisu dostupné, kopii jsem pořídil 18. 6. 2014.

7 Srov. výběrový přehled reakcí: (c) Roman BALÁŽ, Vraždit novorozeňata s těžkým postižením? Tak to jste přestřelil, doktore Mitlöhnere!, Sociální revue (on-line), dostupné na: http:/ / socialnirevue.cz/item/vrazdit-novorozenata-s-tezkym-postizenim-tak-to-jste-prestrelil-doktoremitlohnere, citováno dne 31. 12. 2014; (C) Libor NOVOSÁD, Kdo je vlastně ta monstrózní malformovaná zrůda?, Sociální práce/Sociálná práca (on-line), dostupné na: http:/ / www.socialniprace.cz/ zpravy.php?oblast=1\&clanek=216, citováno dne 31. 12. 2014; (C) Zdeňka DOHNALOVÁ a kol., Pedagogové ze škol v ASVSP odsoudili obsah článku o souvislostech narození člověka s postižením, Sociální práce/Sociálná práca (online), dostupné na: http:/ / www.socialniprace.cz/zpravy.php?oblast=1\&clanek=217, citováno dne 31. 12. 2014; C Radka JANEBOVÁ, Článek Miroslava Mitlöhnera nebyl výzvou k diskuzi a neměl by být obhajován, Sociální práce/Sociálná práca (on-line), dostupné na: http://www. socialniprace.cz/zpravy.php?oblast=1\&clanek=226, citováno dne 31. 12. 2014; @) Václav KRÁSA, Informace č.: 45-2014 (článek o dětech s vývojovými vadami), web Národní rady osob se zdravotním postižením ČR (on-line), dostupné na: http:/ / www.nrzp.cz/aktualne/informacepredsedy-nrzp-cr/1209-informace-c45-2014-clanek-o-detech-s-vyvojovymi-vadami.html, citováno dne 31. 12. 2014. Pro vyčerpávající přehled odkazů viz (C Jiří STODOLA, Vědecká etika: př́ipad Mitlöhner, Inflow (on-line), dostupné na: http:// www.inflow.cz/vedecka-etika-pripadmitlohner, citováno dne 31. 12. 2014.

8 Srov. (C) Radim UZEL, Zrůda není sprosté slovo, ale tragédie, Neviditelný Pes (on-line), dostupné na: http://neviditelnypes.lidovky.cz/ zdravotnictvi-zruda-neni-sproste-slovo-ale-tragedie-pcv-/p_veda.aspx?c=A140623_194847_p_veda_wag, citováno dne 24. 6. 2014.

9 Srov. (C) David ČERNÝ - Tomáš DOLEŽAL, Smíme zabíjet těžce postižené novorozence?, Reflex, 23. 6. 2014 (on-line), dostupné na: http:// www.reflex.cz/clanek/komentare/57269/smime-zabijet-tezce-postizene-novorozence.html, citováno dne 31. 12. 2014.

10 Budu vycházet striktně z textu Mitlöhnerova článku (v jeho dvou verzích) a ponechám zde zcela stranou Mitlöhnerova následná vyjádření v rozhovorech pro servery iDNES.cz a lidovky.cz, v nichž se pokouší reinterpretovat, popřít či „odvysvětlit" některé své teze, fakt autoplagiátorství apod. (Srov. ( ) Petr ZÁLESKÝ, Termín zrůda pro těžce postižené děti byla jen citace, brání se vědec, iDNES.cz, 20. 6. 2014 [on-line], dostupné na: http://hradec.idnes.cz/rozhovor-s-vedcem-miroslavem-mitlohnerem-fij-/hradec-zpravy.aspx?c=A140620_2075379_hradec-zpravy_ kvi\#utm_source=sph.idnes\&utm_medium=richtext\&utm_content=clanek-box, citováno dne 31. 12. 2014; (C Hana MAZANCOVÁ, „Za svým textem si stojím, říká učitel, který chtěl ,zabíjet postižené děti“", lidovky.cz, 23. 6. 2014 [on-line], dostupné na: http://www.lidovky.cz/zasvym-textem-si-stojim-rika-ucitel-ktery-chtel-zabijet-postizene-1fv-/zpravy-domov.aspx?c=A140622_123759_ln_domov_hm, citováno dne 31. 12. 2014). Pro moji kritickou reakci na jeden $z$ těchto pokusů viz @ Lukáš NOVÁK, Mitlöhner a Uzel lžou, Neviditelný pes, 27.6 . 2014 (online), dostupné na: http://neviditelnypes.lidovky.cz/polemika-mitlohner-a-uzel-lzou-dzx-/p_veda.aspx?c=A140625_231409_p_veda_wag, citováno dne 31. 12. 2014. 
čtu, který lze vyčíslit na prstech jedné ruky? To je bohužel selhání redakce časopisu, za které doposud nepřijala odpovědnost.

Postoj redakce navíc budí dojem jisté schizofrenie: výše uvedené vyjádření z webu časopisu velmi brzy zmizelo, pak se znovu objevilo, aby následně zmizelo již definitivně, takže v současnosti není oficiální postoj redakce nijak spolehlivě dohledatelný. To budí dojem, že se k němu redakce vlastně zas až tolik nehlásí (odhlédneme-li od faktu, že stabilita a trvalá dohledatelnost elektronického obsahu je základním znakem serióznosti příslušného média). Tento dojem je umocněn skutečností, že ve svých kritických vyjádřeních k mediálnímu ohlasu kauzy zástupci redakce Doležal a Černý víceméně pomíjejí skutečnost, že článek je autoplagiátem, a pokoušejí se hájit jeho publikaci jako relevantního příspěvku do vědecké diskuse - která byla ovšem podle nich zmařena hysterickou reakcí veřejnosti. Ačkoliv se autoplagiátorská rovina celé aféry jeví v posledku jako ta nejméně důležitá (alespoň jak budu argumentovat níže), přesto $\mathrm{v}$ žádném případě nejde o aspekt, který by bylo možné $\mathrm{v}$ akademickém prostředí opomíjet - a to tím méně, čím více se jej aktéři snaží zametat pod koberec a odvádět od něj pozornost. Bez permanentního nekompromisního postoje akademické komunity k prohřeškům proti etice vědecké práce zákonitě dojde $\mathrm{k}$ tomu, čeho jsme svědky na rovině správy věcí veřejných: $\mathrm{k}$ všeobecné otupělosti $\mathrm{k}$ podvodům a podvůdkům a nakonec $\mathrm{k}$ rezignaci a smíření $\mathrm{s}$ tím, že podobné švindly jsou běžnou součástí akademického života.

\subsection{Podvodné čerpání veřejných zdrojů}

Jak bylo zmíněno, autor deklaruje svůj text jako výstup projektu EU financovaného v rámci operačního programu Vzdělávání pro konkurenceschopnost 2007-2013. Pokus prezentovat jako výstup projektu článek 30 let starý tudíž není „pouhým“ porušením etiky vědecké práce, ale rovněž zneužitím veřejných prostředků. Mám za to, že minimálním adekvátním důsledkem takového jednání by mělo být vyloučení dr. Mitlöhnera z řešitelského týmu (nevyvodí-li odpovědnost sám a neodstoupí-li). Z dostupných informací na webu se však zdá, že k tomu nedošlo - a to i přes informaci v tisku, ${ }^{11}$ že rektor přijal Mitlöhnerovu rezignaci a nařídil okamžitou kontrolu celého projektu. Ještě po půl roce je Mitlöhner stále veden jako člen řešitelského týmu na pozici "Junior vědec" (sic!). ${ }^{12}$

\subsection{Odborná úroveň článku}

Vedle skutečnosti, že článek je autoplagiátem, je též nutné konstatovat jeho nepřijatelně nízkou vědeckou úroveň. Nejedná se přitom pouze o výše zmíněnou absenci reflexe odborné diskuse na dané téma, ale o absenci elementární argumentace a vědecké metodologie vůbec: spíše než vědecký článek text připomíná ideologickou agitku. Zdokumentujme nízkou odbornou úroveň článku alespoň v několika konkrétních bodech.

V první větě autor píše, že „smyslem tohoto článku není řešení filozofických, etických a právních problémů, které se k narození těžce malformovaného jedince váží, ale pokus poukázat na tento nepochybně závažný problém v širších souvislostech“. V článku však autor provádí pravý opak: reflexe širších souvislostí zcela chybí, zato autor prakticky bez argumentace předkládá svá řešení souvisejících problémů jak filosofických (dozvídáme se v několika větách, v čem spočívá lidství člověka či jak máme chápat jeho společenskou a biofyzickou povahu

11 Srov. např. iDNES.cz: (C) Vědec mluví o postižených jako o zrůdách, pobouřil handicapované, iDNES.cz, 19. 6. 2014 (on-line), dostupné na: http://zpravy.idnes.cz/clanek-miroslava-mitlohnera-pobouril-radu-postizenych-pi6-/domaci.aspx?c=A140619_132234_domaci_pvc\#utm_ source=sph.idnes\&utm_medium=richtext\&utm_content=top6, citováno dne 31. 12. 2014.

12 Srov. (C) Členové týmu, in: rodina UHK (on-line), dostupné na: http:/ / rodina.uhk.cz/cs/clenove-tymu, citováno dne 31. 12. 2014. 
- str. 49-50), tak etických (autor má např. pohotově apriorní stanovisko ohledně humánnosti umělého přerušení těhotenství - str. 50) a právních (autor navrhuje změnu legislativy str. 53); a celý článek je vlastně agitací pro to, co autor nazývá „,nezbytným posunem v etickém, filosofickém, morálním i právním myšlení" - str. 50. Není si snad autor vědom toho, co píše? Nebo má snad první věta ospravedlnit katastrofálně nedostatečný zpưsob, jímž se autor ony filosofické, etické a právní problémy pokouší řešit?

Bohorovnost, s níž autor bez jakéhokoliv argumentu prostě sděluje, co si má čtenář myslet, je ohromující:

„Současné přístupy k možnosti ukončení života těžce malformovaného jedince bezprostredně po porodu jsou zbytečně opatrné a jedinou racionální námitkou proti bezbolestnému ukončení života bytosti, která je žrejmou zrůdou ve smyslu odedávných názorů, by mohly být těžkosti s vymezením, od jakého momentu zrůdnost začíná..."13

„Společenskost bytosti (lidské) je třeba chápat nejen jako kvalitu a kvantitu společenských vztahů mezi jednotlivými lidmi, ale i jako schopnost člověka se společensky realizovat, tj. být schopen bezprostředně nebo do budoucna vědomě či uvědoměle využivat faktického stavu své biologické existence..."

„Nelze vystačit s torzením, že je třeba hledět na těžce malformovaného jedince jako na těžce nemocnou osobu, které je třeba za všech okolností poskytovat veškerou dostupnou a možnou lékařskou péči nezbytnou $k$ udržení života..." 15

"Nemá prece smysl prodlužovat život novorozence, který přišel na svět jako monstrum a je pře[d]určen ještě pred soým narozením $k$ smrti..." ${ }^{16}$

Ani pro jedinou z těchto zcela zásadních tezí neuvádí autor žádný argument.

Tím to však nekončí: dogmaticky předkládané vlastní filosofické, etické a právní názory Mitlöhner prokládá neuvěřitelnými báchorkami, které vydává za historická fakta (a to aniž cituje jakékoliv zdroje): ve středověku prý „byly zrůdy považovány za bytosti nadpřirozené nebo za zplozence d'ábla a často spolu s matkou končily svůj život na hranici“ (str. 50, komen-

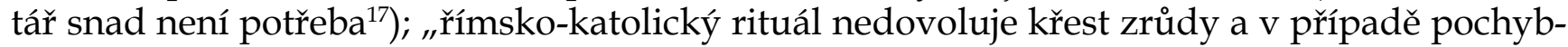
nosti o lidskosti bytosti připouští pouze podmíněný křest" (str. 51) ${ }^{18}$ apod.

V tomto výčtu zásadních metodologických nedostatků by bylo možné pokračovat; ovšem je otázka, zda si vůbec text tohoto druhu takto podrobnou pozornost zaslouží. Jak je totiž zřejmé, nelze jej v žádném případě pokládat za vědecký, za příspěvek do odborné diskuse. Nebylo by tedy adekvátní na něj jako na relevantní odborný text reagovat (a tím jej jako součást odborné

\footnotetext{
13 Autoplagiát, s. 51.

14 Tamtéž, s. 50.

15 Tamtéž.

16 Tamtéž, s. 51.

17 Poukažme zde snad alespoň na jednu položku odborné literatury nabízející stř́izlivý a do kontextu zasazený př́istup k otázce vnímání „monster" ve středověku: Andrew N. SHARPE, Foucault's Monsters, the Abnormal Individual and the Challenge of English Law, Journal of Historical Sociology. September 2007, roč. 20, č. 3, s. 384-403.

18 Ve starších verzích Rituálu se vyskytuje formulace „Monstra et ostenta semper baptizentur saltem sub conditione...“ (t. 2, c. 1, n. 22), takže ve skutečnosti Rituál naopak přikazuje křest $v$ každém případě alespoň pod podmínkou, je-li pochybnost o lidskosti (tatáž formulace je též ve starém CIC [1917], can. 748). Nové (pokoncilní) dokumenty již „monstra“ nezmiňují, z čehož lze vyvodit, že nepřipouštějí pochybnost o lidskosti vůbec, ani v př́ípadě těžké malformace.
} 
diskuse legitimovat); adekvátní reakcí je právě pouze poukaz na skutečnost, že se o text hodný věcné diskuse nejedná. ${ }^{19}$

\subsection{Obsahově-etická stránka textu}

Co však pokládám na celém textu za nejhorší, je jeho obsahově-etická stránka, neboli, řečeno bez obalu, morální odpudivost názorů, které Mitlöhner hlásá. Jako nepřijatelné se jeví především tři aspekty Mitlöhnerovy myšlenkové konstrukce:

1) Svým voláním po infanticidě „zrůd“ ${ }^{20}$ Mitlöhner neguje přirozenou do̊stojnost lidské osoby, její přrirozené právo na život, které je i pozitivně zakotveno v mnoha platných právních normách. ${ }^{21}$

2) Tím, že volá po provádění těchto zákroků bez ohledu na vůli rodičů, navíc popírá přirozené právo rodičů na péči o své děti, které je rovněž zakotveno i v našem právním řádu.

3) Svojí redukcí lidské osoby na její biologickou a společenskou stránku (přičemž tu druhou pokládá za podstatnější a vykládá ji v posledku z kolektivistických pozic, viz níže) otevírá dveře ke zpochybnění práva na život u dalších skupin lidí, jejichž biologický a společenský život je nějakým způsobem poškozen - v logice Mitlöhnerovy koncepce totiž biologický či společenský handicap automaticky znamená omezení lidskosti daného jedince.

Že takové názory zastává někdo jako JUDr. Mitlöhner - právník vystudovaný v 50. letech, později normalizační soudce a vedoucí oddělení všeobecné legislativy Ministerstva spravedlnosti České [socialistické] 22 republiky v letech 1975-1985, nositel medaile "Za službu míru“ a v současnosti člen agresivní Společnosti pro plánování rodiny a sexuální výchovu -, to vskutku nepřekvapuje. V této souvislosti ovšem stojí za to identifikovat těch několik málo úprav, které Mitlöhner ve svém textu provedl, aby zamaskoval jeho stáří a pưvodní kontext. Aktualizovány (nebo vypuštěny) byly samozřejmě odkazy na obsolentní právní normy, z „většiny socialistických zemí“ se stala „většina evropských zemí", autor odstranil marxistickou ideologickou frazeologii („buržoazní právní doktrína“ $\rightarrow$ "právní doktrína v 19. století“), již se neodvolává na "socialistický humanismus“ ${ }^{23}$ atp. Nejpozoruhodnějším zásahem je však odstranění celé jedné věty tvořící v původním článku samostatný odstavec (což podtrhuje její klíčovou roli):

\section{"Hlavní hodnotou není fakt naší existence, ale přínos našeho života pro společnost. ${ }^{24}$}

Na této větě je pozoruhodné, že je vlastně pregnantním vyjádřením onoho „socialistického hu-

$19 \mathrm{~K}$ tomu viz podrobněji kap. 3.

20 Mediální průběh kauzy se poněkud nešt́astně soustředil na Mitlöhnerovo užívání termínu „zrůda“ o těžce postižených lidských bytostech. Ačkoliv tento slovník jistě něco vypovídá o Mitlöhnerově postoji $\mathrm{k}$ těmto bytostem, v kontextu nesrovnatelně podstatnějších aspektů celé kauzy se jedná o marginálii, která pouze odvádí od jádra problému.

21 Zejména Všeobecná deklarace lidských práv, čl. 3; Listina základních práv a svobod, čl. 6; Úmluva o ochraně lidských práv a základních svobod, čl. 2; Listina základních práv EU, čl. 1-3.

22 Mitlöhner toto slovo ve svém životopise vypouští: srov. (c) Detail osoby JUDr. Miroslav Mitlöhner, CSc. (on-line), dostupné na: https:// www.uhk.cz/cs-CZ/UHK/Header/rozsirene-vyhledavani?lideId=uhk-mitlomil, citováno dne 13. 6. 2014.

23 Věta „Problém těžce malformovaných jedinců je nesnadný a socialistický humanismus nedovoluje zavírat oči nad vegetací těchto jedinců a tragediemi jejich nejbližšího okolí“ (původní článek, s. 110) byla změněna na „Problém těžce malformovaných jedinců je sice nesnadný, ale nedovoluje zavírat oči nad vegetací těchto jedinců a tragédiemi jejich nejbližšího okolí" (autoplagiát, s. 50). Tato úprava je dobrým př́kladem, jak Mitlöhner pokusem maskovat svá skutečná ideová východiska ještě zhoršuje již tak chabou argumentační výstavbu článku. Říci, že "socialistický humanismus nedovoluje...“, představuje jisté vysvětlení, náznak aplikace obecných principů na konkrétní případ. V pozměněné formulaci, „problém... nedovoluje...“, již nejde o nic jiného než o myšlenkově vyprázdněné klišé, floskuli bez náznaku zdůvodnění.

24 Původní článek, s. 110. 
manismu“ jako základního Mitlöhnerova filosofického východiska - jeho představy o povaze a zakotvení důstojnosti lidské osoby, ze které poté logicky vyplývají všechny jeho konkrétní teze. Samozřejmě: spočívá-li hodnota člověka v jeho př́nosu pro společnost, potom jedinec, jehož existenci společnost za přínosnou nepokládá - a je celkem jedno, na jakém základě a zda je narozený, či nenarozený -, prostě hodnotu nemá. A co nemá hodnotu, toho se zbavme - přičemž pravomoc přijmout toto rozhodnutí samozřejmě nepatří primárně rodičům s jejich případnými "emocionálními a etickými zábranami“, které je tř̌eba "překonat", ${ }^{25}$ nýbrž společnosti reprezentované všemocným polobohem v bílém plášti, jenž je nad takové malichernosti povznesen, nebot' reprezentuje vyšší zájmy Státu (Strany, Národa...), a tedy bez okolků usmrtí vaše dítě, pokud usoudí, že není schopno dostatečně "lidského“, rozuměj pro společnost přínosného, života. Nacisté měli pro společností takto odepsané jedince přiléhavý termín "lebensunwertes Leben" a dovedli tuto teorii do důsledků s typickou důkladností, k níž Mitlöhnerovi zatím mnoho chybí. Nenavrhuje ještě utrácení nevyléčitelně nemocných, postižených, přestárlých a dalších společnosti nepohodlných osob, zůstává, alespoň prozatím, pouze u „zrůd “. Logika jeho koncepce je však zcela zřejmá; a nejde samozřejmě o nic jiného než o kolektivistickou ideologii vlastní komunistickému režimu, jemuž Mitlöhner tak dlouho sloužil, která se však ve svých základních principech nijak zásadně neliší od ideologie nacistické a kterou náš autor zjevně stále vyznává, ačkoliv už se k jejímu základnímu principu stydí nebo bojí přihlásit explicitně. Škrtnutím jedné věty, o které zřejmě usoudil, že by ji dnešní odborná veřejnost již nevydýchala, však nemůže celkovou vnitřní logiku svého ideologického manifestu nikterak zakrýt.

Jak již bylo řečeno, na tom, že podobné názory hlásá pohrobek komunistického režimu, není nic tak překvapivého a samo o sobě by ještě nešlo o nic alarmujícího - je přirozené, že ve společnosti existuje určité procento zarytých komunistů, stejně jako určité procento zarytých „nácků“. Za mnohem více znepokojivý pokládám fakt, že tyto názory jsou odbornou veřejností namnoze akceptovány jako legitimní příspěvek do diskuse. Že na rozdíl od společenské a intelektuální izolace, $\mathrm{k}$ níž jsou spontánně a po právu odsouzeni zastánci zrůdných ideologií nacismu, rasismu a jim podobných, se komunistický ideolog Mitlöhner dlouhodobě hřeje na výsluní odborné př́izně, zastává vysoké posty v akademických institucích, je členem různých vědeckých společností, dostává granty na své projekty atd. Toto je to největší selhání v celém případu - a nejde o selhání jednotlivce Mitlöhnera, nýbrž o selhání celé odborné veřejnosti. Jak jsem očekával, po vzplanutí Mitlöhnerovy kauzy se tato veřejnost (nebo alespoň její část) pokusila očistit Mitlöhnerovou exemplární ostrakizací. Z výše uvedeného by však mělo být zřejmé, že jakkoliv je rázné řešení tohoto případu potřebné alespoň jako první vlaštovka, samo o sobě rozhodně nestačí k uzdravení mravně zatuchlého klimatu, a pokud Mitlöhner poslouží pouze jako beránek, jehož obětováním se odborný establishment opětovně utvrdí v sebeklamu, že jinak je vše v pořádku, tím hůře. A jak se zdá z vyjádření Doležala a Černého o „honech na čarodějnice“" a z jejich volání po odborné diskusi o Mitlöhnerových názorech, toto nebezpečí vskutku hrozí.

\section{K legitimitě mravní ostrakizace}

Přesvědčení o tom, že článek JUDr. Mitlöhnera neměl být publikován mimo jiné také z obsahově etických di̊vodů, vyjádřili též někteří účastníci výše zmíněné diskuse na webu Zdravotnické právo a bioetika (např. Mgr. Zuzana Candigliota). ${ }^{26} \mathrm{Na}$ to zareagoval šéfredaktor doc. Tomáš

25 Srov. autoplagiát, s. 53.

26 Viz pozn. 3. 
Doležal argumentací, v níž připouští nízkou odbornou úroveň textu, odmítá však myšlenku, že by samotná etická nepřijatelnost Mitlöhnerových názorů měla být důvodem neotištění článku. Doležal píše:

"Co se týče obsahových náležitostí, nemohu souhlasit s tím, že by se v recentních teoretických bioetických úvahách neobjevovaly odborné články či monografie, které se domnívají, že infanticida není nemorální (nap̌r. zejména u vlioného bioetika Petera Singera, dále pak u Petera Tooleyho či Alberto Giubilini a Francescy Minervy). Jedná se zejména o skupiny filosofü, kteři priznávají morální status osobám na základě jejich kognitioních funkcí (bytost schopnou perspektioy proní osoby), nikoliv na základě jeho ontologického pojetí jako individua určitého druhu. Vzhledem $k$ tomu, že se taková kontroverzní témata objevuji, nedomníváme se, že by na akademické pưdě bylo vhodné takovéto přispěvky zakazovat, či omezovat, byt’ se se závěry př́spěvků redakce našeho časopisu nemusí ztotožňovat. Domníváme se totiž, že nejohodnější obranou je diskuse a argumentační obrana, resp. racionální analýza prokazujicí, že teze zastávané autory je možné vyvrátit. Počítáme s inteligentním čtenářem, který si vytvoři na základě takové argumentace vlastní názor." 27

Klíčové je zde zřejmě tvrzení, že vzhledem k tomu, že se taková kontroverzní témata objevují, není vhodné na akademické půdě takovéto př́ispěvky zakazovat či omezovat. Jak je zjevné z toho, co jsem napsal výše, s tímto názorem doc. Doležala nesouhlasím; je tedy na místě, abych svůj nesouhlas obhájil. O to se pokusím v této části svého př́ispěvku.

Z Doležalova textu není zcela jasné, zda svoji pozici zastává z důvodů pragmatických, anebo principiálních: jinými slovy, zda se domnívá, že vyřazovat jakýkoliv kultivovaně formulovaný názor $^{28} \mathrm{z}$ akademické diskuse pouze na základě jeho etické nepřijatelnosti je principiálně nesprávné, anebo má pouze za to, že akademická diskuse je pragmaticky efektionějším způsobem, jak takový názor „zneškodnit“, než by bylo jeho apriorní vyloučení z diskuse. Níže se budu věnovat oběma alternativám. Mimoto bychom ještě měli rozlišit dva aspekty „připuštění názoru do diskuse" - totiž za prvé svolení, aby takový názor v akademickém prostředí vůbec zazněl (tj. např. připustit publikaci článku, který jej vyjadřuje a hájí, v odborném periodiku), a za druhé skutečné otevření diskuse tím, že na článek bude reagováno.

Přesvědčení o principiální nesprávnosti vyřazení nějakého názoru z akademické diskuse se zakládá na předpokladu, že je možné a žádoucí pěstovat „akademickou sféru“ jako naprosto otevřenou, hodnotově a názorově neutrální platformu střetu názorů. Domnívám se však, že taková představa je iluzí. Akademická sféra - jako ostatně žádná společenská či kulturní instituce - nemůže být hodnotově neutrální. Kdekoliv totiž existuje nějaká jakkoli organizovaná lidská činnost, tam eo ipso existuje finalita, zaměření k cíli, a to at' už je reflektováno, nebo nikoliv, a tedy jsou zde přinejmenším implicitně přijímané hodnoty. Samotné přesvědčení, že je žádoucí, aby akademická sféra byla hodnotově neutrální, je hodnotovým soudem (a tedy jde o pragmaticky nekonsistentní požadavek). Ve skutečnosti tedy otázka nezní, zda akademický diskurs má předpokládat nějaké společně respektované hodnoty, nebo ne - bez nějakého hodnotového zakotvení by nemohl vůbec existovat -; skutečnou otázkou je, jaké ty hodnoty maji být. Bylo by bláhové domnívat se, že moderní akademická sféra se byt' i jen blíží hodnotové neutralitě - ve skutečnosti v ní vládne značný počet velmi tvrdě vynucovaných etických tabu (z nichž některá pokládám za zcela na místě, jiná za velmi diskutabilní). Zkuste na akademické

27 Viz pozn. 3; dále viz Doležalův a Černého článek v Respektu citovaný v pozn. 9. K podobné pozici se přihlásili i někteří další diskutující, např. Tomáš NOVOTNÝ: „Článek není kvalitně napsán z hlediska argumentace, citace či pouhé definice tématu a utřídění myšlenek [...] Téma je zcela legitimní, jen text je napsaný naprosto nekvalitně."

28 Odhlížíme nyní od toho, že Mitlöhnerův názor vědecky kultivovaně formulován nebyl. 
platformě např. zpochybnit nemorálnost holocaustu, obhajovat represe proti homosexuálům apod. - výsledkem bude s největší pravděpodobností konec Vaší akademické kariéry.

$\mathrm{Z}$ toho, že koncepce "hodnotového neutralismu“ je vnitřně rozporná a v praxi nerealizovatelná, ještě nevyplývá, že odmítané názory mají být zcela vyloučeny $z$ diskuse; tím méně, že by z diskuse měly být vyloučeny konkrétně názory Mitlöhnerovy. Je tím ukázáno pouze to, že proti „vylučování $\mathrm{z}$ diskuse“ nelze legitimně argumentovat principiálně, $\mathrm{z}$ „, hodnotově-neutralistických" pozic. Hledání odpovědi na otázku, zda je přípustné, nebo dokonce žádoucí, aby byly některé názory z akademického diskursu vyloučeny, se musí odehrávat na rovině konkrétní hodnotové argumentace: diskuse bude o tom, které hodnoty jsou pro akademický diskurs závazné a co z toho vyplývá.

Vzhledem k tomu, že akademická diskuse je lidskou aktivitou, nemůže být jako taková vyňata z obecně lidských kritérií mravnosti. At' už tedy budeme spatřovat specifické cíle a hodnoty akademického "provozu“ v čemkoliv, nemohou být v rozporu s obecně lidskými hodnotami ba spíše naopak, měly by k nim být v úzkém vztahu jako jejich konkrétní realizace či aplikace. Můžeme snad jako poměrně nekontroverzní předpoklad přijmout tezi, že mezi specifické cíle a hodnoty akademického diskursu patří na prvním místě pravdivé a zdůvodněné poznání; a je pravda, že dosahovat takovéhoto poznání lze nejlépe v prostředí zaručujícím svobodnou diskusi a "bádání". Odtud se zdá být snadno vyvoditelný požadavek ideálně naprosté svobody názorů a argumentace, a tedy zákaz apriorní „diskriminace“ jakýchkoliv názorů, byt" by útočily např́íklad i právě na ty hodnoty, které akademický diskurs ustavují a umožňují. Taková argumentace by však zapomínala na to, že specificky akademickým hodnotám jsou nadřazeny hodnoty obecně lidské (nebot' akademický diskurs patrně není nejvyšším dobrem člověka zdařilý a hodnotný lidský život lze prožít i zcela bez něj). Kdykoliv by tedy důsledné lpění na těch prvních ohrožovalo ty druhé, bylo by zcela legitimní, nebo dokonce povinností svobodný akademický diskurs obětovat, aby nemusela být obětována lidskost.

Domnívám se, že tento fakt bude každému zřejmý na jasných příkladech: představme si, že by nějaký moralista vypracoval velmi přesvědčivou, akademicky korektní argumentaci pro nadřazenost germánské rasy a mravní oprávněnost holocaustu, anebo pro mravní přípustnost mučení dětí pro potěšení. Měli bychom trvat na tom, že takový názor má právo být akademicky hájen, že jde o legitimní diskusní stanovisko? Anebo by lidsky a eticky adekvátním postojem bylo, že takový názor takříkajíc nepatř́ do slušné společnosti, a tedy bude zcela legitimně z akademické diskuse vyloučen? Přinejmenším legislativy evropských států se jednoznačně hlásí ke druhé možnosti, nebot' chápou, že svoboda akademického bádání je sice důležitá hodnota, rovná a nezpochybnitelná důstojnost všech lidských osob je nicméně hodnotou mnohem základnější a důležitější, a v př́ípadě střetu má tedy přednost. A troufám si tvrdit, že Mitlöhnerův útok na elementární lidskou důstojnost těžce postižených dětí, na právo rodičů bránit dobro svých dětí atd. představuje zcela srovnatelný př́pad s těmi výše uvedenými.

Tím nechci zastávat tezi, že extrémně nemorální názory a argumenty by neměly být vůbec předmětem akademického zkoumání, že by o nich mělo být zakázáno přemýšlet atd. Právě naopak - bez náležitého racionálního zdůvodnění nemůže ani společensky hluboce zakořeněná úcta k lidským hodnotám dlouhodobě obstát. Říkám pouze, že by neměly být připuštěny do akademického diskursu jako legitimní, akademicky hájitelná pozice, v roli partnera (akademická legitimizace nějaké pozice přece není nutnou podmínkou jejího teoretického zkoumání). To konkrétně znamená první ze dvou výše rozlišených možností chápání obratu „nepřipustit do diskuse“. Je samozřejmé, pokud na nějaké platformě podobné názory již zazní a jsou vážně hájeny, že by akademická obec měla kriticky reagovat - to ovšem nutně neznamená diskutovat 
s obhájci holocaustu či mučení dětí jako s partnery, legitimizovat jejich názory jejich vpuštěním na standardní akademické platformy. Jak už bylo řečeno, adekvátní reakcí v takovém případě je právě - jistěže co nejprecizněji vyargumentovaný - poukaz na to, že zastánce takových pozic se pro mravně zodpovědného diskutujícího relevantním partnerem stát nemůže.

Doležalův poukaz na akademickou etablovanost autorů jako je Singer či Tooley je tudíž irelevantní: pokud již nějaké mravně nepřijatelné názory na akademickou půdu vstoupily, nezbývá nic jiného, než na ně adekvátně reagovat (způsobem výše popsaným) a usilovat o to, $z$ akademického diskursu je opět vytlačit. Z toho však nijak nevyplývá (ba spíše je s tím v rozporu) povinnost či potřeba otevř́t prostor pro akademickou prezentaci těchto názorů dalšímu $z$ jejich zastánců - navíc v situaci, kdy v českém prostředí zatím podobné extrémní pozice žádnou zásadní akademickou podporu nedostaly.

Možná však Doležal nechtěl obhajovat připuštění Mitlöhnera do akademické diskuse z principiálních, ale spíše pragmatických pozic (jeho formulace by tomu nasvědčovaly). Možná má za to, že se jedná o natolik slabě odůvodněné názory, že právě v akademické diskusi se nejefektivněji „znemožní“, a tím zneškodní.

Takové přesvědčení by sice nepostrádalo jistou logiku (zvlášt́ vezmeme-li v potaz suterénní úroveň Mitlöhnerova textu), přesto však mám za to, že by bylo značně naivní (a upřímně řečeno pochybuji, že je Doležal [či Černý] ve skutečnosti zastávají - na to se mi jejich obhajoba akademické relevance Mitlöhnerova článku jeví jako př́liš zapálená). Nebere totiž v potaz skutečnost, že společenský dopad faktu, že se s někým vážně diskutuje na vědecké úrovni, je mnohem podstatnějš́i než to, že dotyčný $\mathrm{v}$ oné diskusi dostal na frak. Akceptovat jistou pozici na akademické platformě typu odborný časopis prostě znamená společensky ji legitimizovat bez ohledu na to, jak v očích akademiků diskuse dopadne. Doležal nepochybně zná několik přesvědčivých argumentů proti Singerově pozici a v mnoha diskusích tyto argumenty již mnohokrát zazněly. ${ }^{29}$ Mělo to však za následek diskreditaci a marginalizaci Singerových názorů? Nikoliv - právě naopak: díky bouřlivosti a rozsáhlosti diskusí, které vyvolal, je dnes pokládán za jednoho z nejvýznamnějších současných bioetiků, takže i sám Doležal argumentuje jeho etablovaností, když obhajuje, proč poskytl prostor Mitlöhnerovi.

Doležal by snad mohl poukázat na to, že to $\mathrm{v}$ př́ípadě Mitlöhnera vzhledem $\mathrm{k}$ nízké úrovni jeho článku nehrozí. Potom však je na místě otázka: pokud si redakce byla vědoma slabé kvality článku, neznamená to, že měl být tím spíše zamítnut $\mathrm{v}$ recenzním řízení, nebo alespoň vrácen autorovi k dopracování? Přijmout článek do odborného periodika totiž znamená signalizovat autorovi, že je pokládán za kvalitní př́spěvek k vědeckému bádání, který je brán vážně; publikovat článek s přesvědčením, že nemá úroveň, pouze za účelem znemožnění autora, by tedy byla zákeřnost, která by neměla mít $\mathrm{v}$ akademickém diskursu místo (ani v takových př́padech, jako je ten Mitlöhnerův).

Domnívám se tedy, že se Doležal mýlí, když říká, že „nejvhodnější obranou je diskuse a argumentační obrana, resp. racionální analýza prokazující, že teze zastávané autory je možné vyvrátit". Ve společnosti svrchovaně racionálně uvažujících bytostí by tomu tak možná bylo ( $v$ takovém světě bychom však asi nemuseli diskutovat o moralitě infanticidy); $v$ reálném životě však má daleko větší váhu legitimita, která se nějakému názoru přizná už tím, že se uzná za

29 Zmiňme zde alespoň jednoho z nejvýznamnějších současných zastánců metafyzicky založené přirozenoprávní etické koncepce a dlouholetého Singerova oponenta Johna Finnise (poslední významné vzájemné střetnutí se odehrálo při veřejné diskusi na univerzitě v Princetonu, 15. 8. 2010). 
akademicky relevantní. Navíc, racionální analýzu vyvracející morálnost infanticidy je možné provést i bez toho, aby se zastáncům takové pozice takováto akademická legitimita poskytla. Doležalovu obhajobu publikace Mitlöhnerova textu tedy pokládám i v tomto bodě za nepřesvědčivou.

\section{Pokrytectví či epistemická nezodpovědnost Mitlöhnerových kritikư?}

Jakkoli mám za to, že celkový přístup T. Doležala, k němuž se přidal i D. Černý, ${ }^{30} \mathrm{k}$ celé kauze je neobhajitelný, ${ }^{31}$ přesto musím dát oběma pánům za pravdu v jednom bodě, a sice když poukazují na skutečnost, že Mitlöhnerem prezentovaná obhajoba infanticidy má úzkou logickou souvislost $\mathrm{s}$ umělými potraty: nelze se konsistentně rozhořčovat nad zabíjením narozených dětí a zároveň obhajovat etickou přípustnost zabíjení dětí nenarozených:

"Chcete potraty? Dostanete i infanticidu. Nechcete infanticidu? Zapomeňte na potraty. Potraty také kdysi vzbuzovaly velké emoce a obavy; a podívejte se dnes. Některé ženy jdou dokonce tak daleko, že považují právo na potrat za zcela základni právo žen, bez něhož by všechna ostatní ztratila svioj smysl. Infanticida také vzbuzuje velké emoce a obavy; uvidíme za pár let. " ${ }^{32}$

Zde musím s Doležalem a Černým souhlasit: společnost, která se mravně rozhořčuje nad Mitlöhnerovými tezemi a přitom hájí své právo zabíjet nenarozené děti, je v lepším př́ípadě zmatená a nekonsistentní, v horším př́ípadě pokrytecká - a protože logika idejí se v dlouhodobém horizontu obvykle nakonec prosadí, ${ }^{33}$ mưžeme skutečně očekávat i proměnu vztahu společnosti $\mathrm{k}$ infanticidě a $\mathrm{k}$ lidským právům dětí v raném stadiu postnatálního vývoje. V této souvislosti přichází na mysl výstižná diagnóza S. Sousedíka:

„O lidských právech se za našich dob mluví velice často. To částečně zastírá tu skutečnost, že naše civilizace dnes nedisponuje žádným v širším měřítku akceptovaným myšlenkovým postupem, jak ideu lidských práv zdưvodnit. Tato skutečnost je znepokojivá, protože má dva povážlivé dopady: Jednak nedovedeme vysvětlit sami sobě - natožpak jiným! -, proč vỉbec lidská práva respektovat. Za druhé nám pak chybí kritéria k posouzení, co lidské právo skutečně je, a co je jen dílčí zvláštností toho kterého civilizačnîho okruhu či dokonce pouhým svévolným požadavkem nějakého vlivného nátlakového uskupení. “34

Je to tak: umíme se ještě rozhořčit nad tím, když někdo pošlapává právo novorozenců na život, žádnými teoreticky pevně zakotvenými principy, z nichž bychom toto právo mohli bezpečně vyvodit, však již jako společnost nedisponujeme.

Ovšem co z toho všeho vyplývá? Snad to, že ten, kdo nenahlíží mravní nepřípustnost zabíjení nenarozených dětí, nemá právo pranýřovat propagaci zabíjení dětí narozených, jehož mravní nepřípustnost nahlíží? Nebo to, že když již česká společnost přijala za své potraty, neměli bychom jí, v zájmu důslednosti, bránit přijmout za své ani infanticidu? Nebo snad to, že Mitlöhnerova obhajoba infanticidy přece není tak strašná, když není „, které již dávno žijí v naší společnosti a jsou někdy dokonce označovány za výdobytek moderní

\footnotetext{
30 Viz článek citovaný v pozn. 9.

31 Nejde jen o obecnou otázku oprávněnosti ostrakizace zastánce hrubě neetických názorů, ale i o prostý fakt, že Doležal a Černý ve své obhajobě Mitlöhnerova textu mlží o jeho skutečném obsahu a zároveň obviňují „novináře“ z jeho dezinterpretace.

32 Viz článek citovaný v pozn. 9.

33 Bylo by např. možné ukázat, že Singerova teorie hodnoty člověka je v podstatě zakódována již v Lockově odmetafyzičtěné teorii osobní identity založené na paměti.

34 Stanislav SOUSEDÍK, Svoboda a lidská práva, Praha: Vyšehrad, 2010, s. 9.
} 
doby“? Anebo si máme podle Doležala a Černého vyvodit, že ve společnosti, která připouští potraty, je právě proto obhajoba infanticidy legitimním předmětem diskuse?

Doufám, že je zřejmé, že takto jednoduše ani jedna z nabízených implikací neplatí. Naopak: shodneme-li se s Černým a Doležalem v tom, že jak potraty, tak infanticida jsou závažným mravním zlem, neměli bychom spíše poukazovat na to, že z (prozatím stále ještě) nepochybné a mimo diskusi stojící nepř́ípustnosti infanticidy vyplývají jisté důsledky i pro mravní status zabíjení nenarozených?

Přesto je na místě klást si otázku, co vlastně vede Doležala a Černého k tomu, že nejsou ochotni zaujmout právě nastíněnou perspektivu. Pokusme se proto proniknout do problému poněkud hlouběji.

Mám podezření, že za Doležalovým a Černého voláním po „smysluplné diskusi“ o Mitlöhnerem prezentovaných tezích se přes veškeré jejich proklamace o „rezolutním nesouhlasu s názory JUDr. Mitlöhnera" skrývá přesvědčení, že tyto názory jsou vlastně docela dobře obhajitelné. Doležal a Černý s nimi sice nesouhlasí, nenahlížejí je však jako zjevně nepřijatelné a odsouzeníhodné (tak, jako např. spontánně odsuzujeme přesvědčení nacistů o méněcennosti Židů), mají za to, že je lze „rozumně“ hájit - zkrátka, přes své vlastní přesvědčení pocit’ují otázku přípustnosti infanticidy jako otevřený, možná dokonce palčivý problém. Proto je pochopitelně irituje pohled těch, kteří Mitlöhnerovy teze za hodny diskuse nepokládají, otázku přípustnosti infanticidy za otevřenou nepovažují a proti jejímu otevření aktivně vystupují.

Ted' jde ovšem o to, který z těchto dvou postojů či epistemických stavů je adekvátnější či žádoucnější - zda ten Doležala a Černého, anebo těch, které kritizují -, a kterou ze stran je tudíž na místě přesvědčovat ke změně. Je patřičnější, rozumnější či lidštější mít za to, že Mitlöhnerovy názory jsou evidentně nelidské, a tudíž nehodné vážné akademické diskuse, anebo by ti, kdo toto přesvědčení zastávají, udělali lépe, kdyby se ho vzdali a (přesně jako Doležal s Černým) připustili, že názory, které Mitlöhner hájí, si zaslouží být vážně vzaty v potaz, zaslouží si „akademický respekt" - a to aniž by v nich dali Mitlöhnerovi za pravdu?

Argumentace Doležala a Černého směřuje druhým nastíněným směrem; a z jejich poukazů na nekonsistenci a principiální nezakotvenost Mitlöhnerových zásadních kritiků lze vytušit i důvod, který pro svoji pozici mají: epistemický postoj svých oponentů zřejmě pokládají tak říkajíc za epistemicky nezodpovědný, tj. nedostatečně epistemicky podložený, dogmatický. Skutečnost, že tomu tak ve většině případů vskutku je, musíme oběma pánům, obávám se, připustit. Nemají však potom pravdu, když tvrdí, že ze strany Mitlöhnerových kritiků se opravdu jedná o iracionální „,hon na čarodějnice“?

Takový argument by se opíral o obecný princip, který lze formulovat následovně: vylučovat nějaký názor z akademické diskuse bez solidního teoretického zdůvodnění je vždy iracionální a nepř́pustné. Na první pohled tato zásada vypadá přitažlivě; můžeme ji však skutečně pokládat za obecně platnou? Že tomu tak není, se pokusím doložit na protipř́íkladu.

V současné společnosti panuje shoda, že jisté názory mají být a priori vyloučeny z akademické diskuse: nikdo např́klad nebude ochoten připustit akademickou diskusi o tom, zda mají Židé stejná práva jako ostatní lidé. Drtivá většina vzdělané veřejnosti zastává tento názor, a kdyby se někdo pokusil takovou diskusi na veřejné půdě otevřít, nepochybně by se i drtivá většina vzdělané veřejnosti důrazně ozvala podobným způsobem, jako k tomu došlo v Mitlöhnerově kauze. Přesto: má drtivá většina vzdělané veřejnosti k dispozici nějaké solidnější teoretické 
odůvodnění univerzality lidských práv? Mám za to, spolu se Sousedíkem, že je evidentní, že nikoliv (a to i kdybychom „vzdělanou veřejnost“ zúžili na "filosoficky vzdělanou veřejnost“), a tuto skutečnost jsem si mnohokrát z vlastní zkušenosti potvrdil. Je-li tomu tak, pak ovšem musíme bud' připustit, že apriorní ostrakizace antisemitských názorů je iracionální a nepř́ipustná, anebo musíme odmítnout výše uvedený princip.

Existuje nějaký pozitivní důvod, proč bychom měli učinit spíše to druhé? Jsem toho názoru, že ano. Zdá se mi, že je zcela přirozené připustit, že zaujímání určitých mravních postojů nemusí být legitimováno pouze teoreticky (prostřednictvím epistemické justifikace poskytnuté nějakou etickou teorií), ale též jakýmsi přirozeně intuitivním způsobem - Tomáš Akvinský např. hovoří o poznání per connaturalitatem, tj. poznání skrze jakousi přirozenou afinitu:

"Správnost soudu může nastat dvojím zpưsobem: jednak na základě dokonalého užívání rozumu, a jednak na základě jakési přirozené afinity viuči tomu, o čem se právě soudí. Např́klad o tom, co obnáší cudnost, soudi správně na základě rozumového zkoumání ten, kdo si osvojil morální vědu; na základě jakési přirozené afinity $k$ těmto věcem pak o nich soudí správně ten, kdo má habitus cudnosti. “35

Je přece evidentní, že lidé zcela běžně zaujímají mravní postoje a rozhodují se pro mravní jednání predevším tímto „intuitivním“ způsobem; teoretická etická úvaha přichází v drtivé většině až jako reflexe přirozených mravních intuic. Máme snad tuto běžnou lidskou praxi prohlásit za iracionální a dogmatickou?

Zdá se mi zjevné, že nikoliv. Tím samozřejmě nechci tvrdit, že by racionální úvaha nemohla a neměla výchozí intuice korigovat, někdy i zcela radikálně. Pokládám však za zcela zřejmé, že $i$ když tato reflexe chybí, není jednání podle silných mravních intuic iracionální (přičemž tomistická teorie poznání skrze connaturalitu může sloužit jako možné vysvětlení toho, proč není iracionální, není však nutná pro obhajobu faktu této racionality - ten je totiž, jak tvrdím, žrejmý).

Jestliže tudíž panuje ve společnosti sdílená mravní intuice, že určité názory jsou zcela evidentně nelidské, pak apriorní vyloučení takových názorů z akademické diskuse není iracionální či dogmatické v pejorativním slova smyslu, i když třeba není k dispozici žádné robustní teo-retické zdůvodnění jejich nelidskosti - přinejmenším v tom ohledu, že břemeno argumentace leží vždy na tom, kdo mravní intuice jevící se jako přirozené zpochybňuje. Kdyby byl Mitlöhner napsal zcela špičkově vyargumentovaný článek vyrovnávající se se všemi relevantními argumenty pro nedotknutelnost lidského života, bylo by snad na místě zvažovat, zda síla jeho argumentů nepřevažuje pozitivní presumpce ve prospěch přirozených mravních intuic a zda by neměl být na akademické fórum připuštěn (odpovědnost toto rozhodnout leží na bedrech recenzentů a redakce př́slušného časopisu). Taková situace však ani vzdáleně nenastala - o vědeckých kvalitách Mitlöhnerova článku viz výše -, a proto Mitlöhnerovi kritici zcela oprávněně a racionálně žádali jeho apriorní ostrakizaci, i pokud tak činili pouze na základě přirozeného smyslu pro mravnost, bez teoretického zdůvodnění, nebo dokonce v rozporu s některými jinými mylnými mravními principy, které zastávají a které s Mitlöhnerovými názory souzní (např. podpora práva ženy zabít své nenarozené dítě).

35 „Rectitudo autem iudicii potest contingere dupliciter, uno modo, secundum perfectum usum rationis; alio modo, propter connaturalitatem quandam ad ea de quibus iam est iudicandum. Sicut de his quae ad castitatem pertinent per rationis inquisitionem recte iudicat ille qui didicit scientiam moralem, sed per quandam connaturalitatem ad ipsa recte iudicat de eis ille qui habet habitum castitatis." - Tomáš Akvinský, Summa theologiae II-II, q. 45, a. 2, co. 


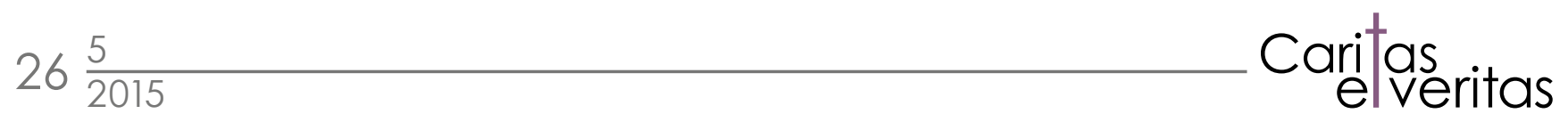

\section{Závěr}

V tomto textu jsem se pokusil ukázat několik aspektů autoplagiátorské kauzy JUDr. Mitlöhnera, které jsou podle mého názoru hodny povšimnutí, a na základě jejich analýzy dospět k racionálnímu pohledu na celou aféru.

Předně je to skutečnost, že samotné autoplagiátorství není zdaleka tím nejhorším aspektem celého případu, který obnáší větší počet někdy daleko zásadnějších selhání. Jako nejvíce znepokojivá se mi v této souvislosti jeví skutečnost, že v současném akademickém prostředí text této kvality a morálního obsahu - v podstatě ideologická agitka starého komunistického aparátčíka - může být pokládán za legitimní předmět seriózní akademické debaty a jako takový hájen.

V souvislosti s tímto případem jsem se též pokusil o obhajobu teze, že z oboru respektovaných diskusních alternativ $\mathrm{v}$ akademickém diskursu by měly být vyloučeny pozice směřující k destrukci elementárních lidských hodnot, a to především lidské důstojnosti jako takové - a to vzhledem $\mathrm{k}$ nadřazenosti obecně morálních hodnot a cílů nad specifickými hodnotami a cíli akademického diskursu. Akademický diskurs totiž neprobíhá ve vzduchoprázdnu ani v hermeticky uzavřené laboratoři, nýbrž ve společnosti, a názory v jeho rámci prezentované a hájené mají své společenské a etické dopady - v době informační globalizace již mnohem silnější a mnohem dřive, než tomu bylo kdykoli v minulosti. Proti T. Doležalovi a D. Černému jsem přitom hájil tezi, že takové vyloučení je oprávněné i tehdy, když se nezakládá na žádné robustní a konsistentní etické argumentaci, ale pouze na přirozeném lidském smyslu pro mravnost.

Na úplný závěr si dovolím vyvodit jedno zcela konkrétní „mravní ponaučeni“: Naši zastánci euthanasie se vesměs stále ještě dušují, že v případě zavedení tohoto výdobytku do našeho právního řádu bude naprosto vyloučeno, aby o usmrcení pacienta rozhodoval kdokoliv jiný než on sám. Může tato ujištění, po seznámení se s Mitlöhnerovými názory a s neschopností části naší odborné veřejnosti je jasně a nekompromisně vyloučit z relevantní bioetické diskuse, ještě někdo vůbec brát vážně?

\section{Aféra JUDr. Mitlöhnera: Analýza prípadu a obecnější souvislosti}

Abstrakł Předmětem diskusní studie je analýza různých aspektů proběhlé autoplagiátorské kauzy JUDr. Mitlöhnera. Autor hájí tezi, že samotné autoplagiátorství není zdaleka tím nejhorším aspektem celého prípadu, který obnáší větší počet někdy daleko zásadnějších selhání. Za nejvíce znepokojivou pokládá skutečnost, že $\vee$ současném akademickém prostředí text takto nízké kvality a takto morálně problematického obsahu mưže být pokládán za legitimní předmět seriózní akademické debaty a jako takový hájen. V této souvislosti autor dále háji tezi, že z oboru respektovaných diskusních alternativ v akademickém diskursu by měly být vyloučeny pozice směřujicí k destrukci elementárních lidských hodnot, a to především lidské důstojnosti jako takové - a to vzhledem k nadřazenosti obecně morálních hodnot a cílů nad specifickými hodnotami a cíli akademického diskursu. V diskusi s T. Doležalem a D. Černým též zastává názor, že takové vyloučení je oprávněné i tehdy, když se nezakládá na žádné robustní a konsistentní etické argumentaci, ale pouze na prïrozeném lidském smyslu pro mravnost.

Klíčová slova Miroslav Mitlöhner, etika vědecké práce, etika vědeckého diskursu, ostrakizace, autoplagiát, infanticida 


\section{The Affair of JUDr. Mitlöhner: Case Analysis and Broader Context}

Abstract The discussion article aims to analyse various aspects of the recent Mitlöhner self-plagiarism affair. The author maintains that self-plagiarism as such is not the worst aspect of the matter, but that there are several much more important failures in the case. The author regards as most disturbing the fact that such a low-quality and morally dubious text can be viewed as legitimate object of academic discussion, and as such be defended, in the present academic milieu. The author further defends the claim that opinions aimed at the destruction of elementary values of humanity, and especially of human dignity as such, should be excluded from the pool of respectable alternatives in academic discourse; the reason being that general moral goods and goals are superior to the specific goods and goals of academic discourse. By way of polemic with T. Doležal and D. Černý the author defends the view that such exclusion is justified even when it is not backed by any robust and consistent ethical reasoning, but merely by natural human moral sense.

Keywords Miroslav Mitlöhner, academic ethics, ethics of academic discourse, ostracism, self-plagiarism, infanticide 